\title{
1 Recent Urban Development Reduces Bee Abundance and Diversity
}

2

3 Vera Pfeiffer ${ }^{1,2}$, David W. Crowder ${ }^{2}$, Janet Silbernagel ${ }^{3,4}$

$4 \quad{ }^{1}$ Nelson Institute for Environmental Studies, University of Wisconsin - Madison, Madison, WI

$5 \quad 2$ Department of Entomology, Washington State University, Pullman, WA

$6 \quad{ }^{3}$ Department of Planning and Landscape Architecture, University of Wisconsin-Madison

$7 \quad{ }^{4}$ Silvernail Studio for Geodesign, LLC

8

9 Corresponding author: Vera Pfeiffer, vera.w.pfeiffer@gmail.com 


\section{Abstract}

11 Wild bee communities persist in cities despite major disruption of nesting and food resources by

12 urban development. Bee diversity and abundance is key for urban agriculture and maintenance of

13 plant diversity, and assessing what aspects of cities enhance bee populations will promote our

14 capacity to retain and provision bee habitat. Here, we assessed how variation in land cover and

15 neighborhood development history affected bee communities in the midwestern US urban

16 landscape of Madison, Wisconsin. We sampled bee communities across 38 sites with relatively

17 high ( $>55 \%$ ) or low ( $<30 \%$ ) levels of impervious surface, and assessed effects of land use and

18 neighborhood development history on bee abundance and species richness. We show abundance

19 and richness of bees was lower in recently developed neighborhoods, with particularly strong

20 negative effects on soil nesting bees. Soil nesting bees and bee community richness decreased as

21 cover of impervious surface increased, but above ground nesting bees were minimally impacted.

22 Bee community similarity varied spatially and based on dissimilar local land cover, only for soil

23 nesting bees, and the overall bee community. Impervious surface limited bee abundance and

24 diversity, but new neighborhoods were associated with greater negative effects. We suggest that

25 enhancing the structural diversity of new neighborhoods in urban ecosystems may imitate the

26 structural benefits of older neighborhoods for bee populations.

28 Keywords: Urban ecosystems, bee community, habitat guilds, habitat filtering, impervious

29 surface, development history

\section{Declarations:}


33 Funding: Department of Entomology, University of Wisconsin-Madison

34 Conflict of interest: The authors declare they have no conflict of interest

35 Availability of data and material: Bees are submitted to the University of Wisconsin-Madison

36 insect museum.

37 Code availability: https://github.com/verawp

38 Author contributions: VWP designed study, performed analysis and drafted manuscript, JSB and

39 DWC participated in manuscript writing. All authors gave final approval for publication.

40 Compliance with ethical standards

41 


\section{Introduction}

Urban development is rapidly transforming the Earth's surface. Impervious surfaces and fragmented patches of vegetation that typify urban ecosystems threaten species diversity (Rebele 1994). In urban ecosystems, ecological communities are also exposed to loss of food and nesting resources, despite cultivated gardens adding diversity (Rebele 1994, Rosenzweig 2003). Urban habitat fragmentation often leads to the loss of plants and associated pollinators, especially plants reliant on animal pollination (Biesmejer et al. 2006; Theodorou et al. 2020). However, organisms differ in their sensitivity to urbanization, and certain pollinators thrive in urban ecosystems despite high disturbance. More research is thus needed to assess relationships between ecological community structure and land use in urban landscapes to protect biodiversity and ecosystem services in ecosystems supporting most of the human population (Daily et al. 1997).

Native bees promote diversity of urban ecosystems by pollinating native, ornamental, and agricultural plants across seasons (Hoehn 2008, Garibaldi 2013). As urban development expands, urban agriculture is growing, emphasizing the need to maintain urban pollinators to produce food where people live (Hodgson et al. 2011). Habitat simplification and high density of honey bee apiaries in urban systems can negatively affect wild bees (Gonzales et al. 2013, Martins et al. 2013; Renner et al. 2021), but high bee diversity has also been observed in cities like New York and Chicago, US (McFrederick and LeBuhn 2006; Matteson et al. 2008; Fetridge et al. 2008). This shows urban land can provide diverse floral resources, especially when gardens provide

64 flowers for a longer duration than other ecosystems (Goddard et al 2010, Threlfall et al. 2015).

65 Urbanization may have different impacts on bees with different ecology, however. 
Within urban ecosystems, variation in pollinator nesting strategy may predict sensitivity of

67 species to the high levels of disturbance in urban systems. In many cases, below-ground nesting

68 cavity bees are expected to be more affected by urbanization than bees that nest aboveground

69 given the prevalence of impervious surfaces (Larsen 2005, Cane et al. 2006; Jha and Kremen

70 2013). For example, many bees excavate or construct their own nesting cavities using mud,

71 wood or pithy stems, or dig cavities in the soil, and these habitats are often less available in

72 urban compared to natural or rural landscapes. However, man-made structures can in some cases

73 supplement nesting habitat, by providing stone walls, wooden structures, and various other

74 cavities, as well as bare ground and loosened soil. By investigating what aspects of land cover

75 and land use underlie trends in species filtering, we can increase our capacity to restore the

76 resources that are lost along with associated taxa.

77 Here we assessed effects of land cover and neighborhood development on the urban bee

78 communities associated with the growing urban cityscape of Madison, Wisconsin, United States.

79 Our study tested three main hypotheses. First, we predicted that property development would

80 increase the amount of impervious surface area, disturbing bee habitat and reducing abundance

81 and species richness of bee communities. In particular, we expected stronger effects of property

82 development on below-ground cavity nesting bees that require already excavated cavity spaces,

83 often underground. Second, we predicted that bee community composition would be more

84 dissimilar with greater geographic distance across the city, especially for small soil-nesting bees

85 with limited dispersal capacity. Third, we predicted that property development would decrease

86 similarity in the composition of bee communities. By assessing effects of land cover, property

87 development, and spatial scale on species richness and species composition of bee communities, 
88 our study contributes to the empirical foundations of pollination ecology as it relates to

89 conservation and restoration efforts in urban ecosystems.

\section{Materials and methods}

\section{Study area and sampling design}

Madison, Wisconsin is an urban state capital surrounded by agricultural land in one of the

94 fastest growing counties in the US. The primary transition type occurring in the Madison area for

95 the past century is the conversion of agricultural to urban land around the city edge (Wegener

96 2001; Carpenter et al. 2007; Riera et al. 2001). The dominant urban area is typified by mixed

97 residential and commercial zones with small forest patches and city parks. The $123 \mathrm{~km}^{2}$ central

98 urban zone of Madison includes $46 \mathrm{~km}^{2}$ (37\%) of impervious surface, $30 \mathrm{~km}^{2}$ (24\%) of vegetated

99 space, with the remaining landscape covered by lakes. The city receives semi-frequent rain and

100 severe thunderstorms throughout the summer months that supports abundant flowering prairie

101 plants in city parks or where native grasslands have been conserved or restored around the city.

102 Flower-visiting insects were sampled across Madison using a spatially stratified survey to

103 account for changing regional species pools. To select sites, a grid of $2.52 .5 \mathrm{~km}$ squares was

104 laid across Madison and cells dominated by lake or agriculture were excluded, leaving 19 cells

105 dominated by high-density residential and urban land (Fig. 1). In each of these cells we used a

106 paired design and selected two sites characterized by either (1) high (> 55\%) or (2) low (<30\%)

107 impervious surface area within the surrounding $200 \mathrm{~m}$ based on a lower resolution classified land

108 cover surface (USDA-NASS 2013). Within each cell, paired sites with high or low impervious

109 surface area were separated by at least $400 \mathrm{~m}$. These 38 sites were selected in a stratified-random 
110 manner, and permission from property owners (identified from a city database) was requested

111 until appropriate locations were identified. Sample sites included primarily residential properties,

112 as well as commercial properties, urban storm water management areas, and city parks.

113

\section{Bee community sampling}

115 Bees were sampled six times between early June and late August 2013. Pan traps were

116 distributed every two weeks during clear, sunny days when bees were foraging. All traps were

117 distributed across the same evening to early morning period (after 17:00-dark and before dawn-

118 8:00), and collected $4 \mathrm{~d}$ later. Six bee traps were placed at least $5 \mathrm{~m}$ apart within a $40 \mathrm{~m}$ area in

119 each site, with two dark blue, two canary yellow, and two white; bees were also trapped in $0.5 \mathrm{~L}$

120 pan traps suspended $20 \mathrm{~cm}$ or $2.5 \mathrm{~m}$ from the ground to match the height of flowering vegetation.

121 Bees were identified to species using the discover life online key and a comprehensive

122 dichotomous key available for Lasioglossum (Ascher \& Pickering 2013; Gibbs 2011).

123 We classified bee taxa as soil-nesting, below-ground cavity-nesting, and above-ground

124 nesting bees, based on available observations. The below ground cavity-nesting bees included 7

125 species of bumble bees (Apidae: Bombus). Above-ground nesting bees included small carpenter

126 bees (Ceratina spp.), yellow faced bees (Hylaeus spp.), carder, mason, and leafcutter bees

127 (Megachilidae), and two sweat bees that nest in decaying wood, Lasioglossum cressonii

128 (Mitchell 1960) and L. oblongum (Sakagami \& Michener 1962). Above-ground nesting bees

129 included 22 species. The rest of the bees were classified as soil nesting bees, which included 69

130 species across several groups: (i) long-horned bees (Tribe Eucerini), (ii) mining bees (Andrena 
131 spp.), (iii) green bees, (iv) all of the other sweat bees, and (v) any others were classified as soil

132 nesting bees, although natural history observation of many species could not be located.

Measuring land cover and neighborhood development around study sites

Six-inch resolution digital aerial images were used to classify impervious surfaces such as

roads, parking lots, and structures. Unsupervised classification was initiated with 30 classes that were clumped into land cover types. The impervious surface layer from this classification was added to the City of Madison building footprint and road layer to recover impervious surface obscured by tree canopy. Natural vegetation was identified visually within $1000 \mathrm{~m}$ of each site and included open canopy, perennial grasses and forbs in greenways, parks, or transportation corridors. Closed canopy forest was also digitized around sites. Each land cover variable was measured as a percent of the landscape, then variables were standardized with a mean of zero and standard deviation of 1 for comparison in analyses. The three land cover types were also

144 consolidated in a distance matrix at each scale. To characterize neighborhood development

145 history, publicly accessible tax assessment data was obtained and property development year was

146 extracted for parcels located within a 200 m radius of each site, from which we extracted an area-

147 weighted average development year for each site. A Bray-Curtis distance matrix was constructed

148 to contrast sites based on the variability of the area-weighted average, median development year,

149 and most recent property development year within the 200m buffer.

\section{Data analysis}


152 Individual-based rarefaction curves were constructed for each site using the ‘vegan’ R package,

153 and rarefaction-based species richness estimates were compared to observed richness (Oksanen

154 et al. 2018). Rarefied richness did not reach an asymptote, so raw abundance and richness values

155 were used as sampling effort was standardized (Fig. 2). We used linear regression models to test

156 whether land cover and neighborhood development (median property development year) affected

157 bee species richness ( $\alpha$-diversity); separate analyses were conducted for the overall community

158 and three bee guilds. All variables were scaled to a mean of 0 and standard deviation of 1 and top

159 models were selected using stepwise AIC model selection using the 'MASS' R package (Ripley

160 et al. 2018). For purposes of comparison we discuss “old” neighborhoods as those with a median

161 development year prior to 1960 and “new” neighborhoods as those with a median development

162 year after 1960. Bee abundance and richness seemed to drop off after this time point, reflecting a

163 qualitative difference rather than a gradual, linear decline. The Moran’s I test was used to check

164 for spatial autocorrelation in model fit for each full and final models, applied using the 'car' R

165 package (Fox et al. 2018).

166 We used multiple regression on distance matrices (MRM) to assess effects of the various

167 explanatory variables on bee community composition at the landscape scale ( $\beta$-diversity), which

168 was implemented through the R package 'ecodist' (Legendre and Legendre 1998; Goslee and

169 Urban 2017). This allowed us to capture the various multifaceted explanatory variables reflecting

170 heterogeneity of land cover and land use history. MRMs measure the effect magnitude of each

171 explanatory distance matrix using a non-parametric framework and pseudo $t$-tests are used to

172 assess significance of explanatory variables (Goslee and Urban 2017). 


\section{Results}

175 We captured 1331 bees at the 38 sites. Across families, 31\% were Apidae, 3\% Andrenidae,

176 55\% Halictidae, 8\% Megachilidae, and 3\% Collitidae. Sites were surrounded by 0 to $43 \%$ natural

177 vegetation $($ Mean $=10.3 ; \mathrm{SD}=9.1)$ and 0 to $28 \%$ forest $($ Mean $=5.0 ; \mathrm{SD}=6.3)$ with median

178 property development varying between 1920 and 2003 (Mean = 1947; SD = 22). All full bee

179 community and soil nesting bee community analyses were performed across all sites $(\mathrm{n}=38)$.

180 Above ground nesting bee and below ground cavity nesting bee analyses were performed across

181 sites where bees from the nesting guild were present, 32 and 17 sites, respectively.

182

183 Effects of recent property development on bee abundance and diversity

184 The average bee abundance decreased from 41.7 to $20.8(t=-2.77, \mathrm{df}=25.98, P=0.01)$,

185 and average species richness from 17.4 to $11.3(t=-2.76, \mathrm{df}=24.16, P=0.01)$, in pre-1960

186 compared to post-1960 median development year neighborhoods (Fig. 3). This was driven

187 mainly by decreases in soil-nesting bees, which decreased in abundance from 28.7 to 13.6 bees,

188 and 11.3 to 7.6 species, from old $(n=29)$ to new $(n=9)$ neighborhoods. The abundance and

189 richness of above-ground nesting bees, and below-ground cavity nesting bees, were similarly

190 abundant and rich in old and new neighborhoods ( $P>0.24$ for all four metrics). In multiple

191 variate linear regression models including development and land cover variables, a negative

192 influence of recent property development was the strongest predictor of overall bee and soil

193 nesting bee species richness, and the term was included with the negative influence of

194 impervious surface in top models (Tables 1, 2).

195 


\section{Effects of surrounding land cover on bee species diversity}

In addition to effects of neighborhood development, the proportion of impervious surface

also reduced the species richness ( $\alpha$-diversity) of the overall bee community, soil-nesting bees,

199 and above-ground nesting bees (Tables 1, 2). The negative influence of impervious surface on

200 the overall richness of bee species and soil-nesting bees were each about half the magnitude of

201 the property development effect in the scaled regression model. For the overall bee community,

202 the regression model indicates a 2.9 factor decrease in bee species richness per $23 \%$ increase in

203 the proportion of impervious surface. The below-ground cavity-nesting bee species richness was

204 negatively associated with surrounding forest cover with a 1.0 factor decrease in bumble bee

205 species with each $12 \%$ increase in surrounding forest cover.

207 Variation in bee community composition across the study extent

208 The final multiple regression on distance matrix model (MRM) for the full bee community composition included only the land cover effect $(P=0.03)$ (Table 3). For the soil nesting bee community, there was a clear influence of geographic distance on community dissimilarity $(P=$

$2110.040)$ and a land cover effect $(P=0.04)$ (Table 3). The below-ground cavity nesting community

212 composition included a weakly significant influence of geographic distance $(\mathrm{P}=0.07)$ (Table 3).

213 And there were no observed effects of geographic distance or land cover on the above-ground

214 bees (Table 3). None of the bee community final models included significant effects of property 215 development on community composition (Table 3).

\section{Discussion}


Bees from each nesting guild were observed throughout the City of Madison at both low

219 and high impervious surface sites. This result suggests that in general, bees are able to use small

220 patches of habitat within the most urbanized landscapes of the city (Theodorou 2016; Hall et al.

221 2016, Daniels et al. 2020). Our observation of an association between impervious surface and

222 reduced bee community richness, especially for soil nesting bees, reflected patterns reminiscent

223 of a 60-year study in Brazil, which documented an increase of impervious surface and decrease

224 in soil bee nests, abundance, and declines of species richness and phylogenetic diversity (Pereira

225 et al. 2020). The negative influence of impervious surface on soil-nesting bees, above-ground

226 cavity-nesting bees, and the entire bee community, may stem from a loss of exposed soil used for

227 nesting habitat, and associated decreases in flowering forbs that bees use as a food resource.

228 Our finding that more recently developed neighborhoods exhibited lower bee abundance

229 and diversity was not based on our initial expectations of mechanistic associations between land

230 cover transformation and bee habitat provisioning. A negative influence of recent development

231 was observed for the full bee community and soil-nesting bees. While this negative effect may be

232 due to disturbance and soil compaction, we also observed a reduction of structural complexity in

233 recently developed neighborhoods surrounded by more grass lawn and less gardens that may

234 provision diverse types of bee habitat. More established neighborhoods more frequently offered

235 more complex built habitat including rock walls and gardens rather than simple lawn land cover.

236 While we expected that below-ground cavity nesting bees would be the most impacted by

237 urbanization and impervious surface, we did not observe that result. Bumble bees that comprised

238 this nesting habitat guild can forage long distances, and other studies have observed bumble bee

239 foraging presence to be strongly influenced by floral resources (Turo et al. 2019, Reeher et al. 
240 2020, Cohen et al. 2020) In fact, greater urban cover can sometimes increase the abundance of

241 urban bumble bees in urban gardens, and promote higher in-garden foraging, alongside plant

242 richness as another contributing factor (O’Connell et al. 2020). Another study of urban bumble

243 bees in the American Midwest found that bumble bee abundance and richness were unaffected

244 by the amount of impervious surface across several cities (Reeher et al. 2020).

245 While geographic distance did not explain the dissimilarity of the full bee community, it

246 contributed to the dissimilarity in soil-nesting and below-ground cavity-nesting bee community

247 composition. This confirmed our hypothesis that generally smaller, soil-nesting bee communities

248 would vary more across the urban study extent. Past studies have confirmed that bee foraging

249 distances are correlated with body size, contributing to patchy distributions of small bee species

250 (Steffan-Dewenter et al. 2002; McKinney 2008). A recent study of pollinators around cotton

251 farms in Texas found no geographic pattern of isolation by distance for bees, but these patterns

252 were observed for beetles and other more movement limited insect taxa (Cusser et al. 2018).

253 Urbanization can also filter bee community composition, with some evidence that urban

254 bee communities are more homogenous subsets of nearby rural bee communities (Banaszak-

255 Cibicka 2020). In the models for the species composition of the full bee community as well as

256 each nesting habitat guild, property development did not appear to filter the species composition.

257 Surrounding land cover did affect the full bee and soil-nesting bee community dissimilarity.

258 While the influence of land cover significantly influenced the dissimilarity of species

259 assemblages, these factors did not explain much of the variation overall. High species richness

260 of bees was observed across the city, as well as patchy distributions of rare species. 
261 Research documenting responses of bee communities to urbanization is on the rise, but a

262 recent meta-analysis only discovered three published studies assessing the relationships between

263 bee traits and urbanization (Buchholz and Egerer 2020). As urbanization processes continue to

264 transform landscapes around the world, improving our understanding of habitat provisioning and

265 ecosystem services in urban ecosystems is of great importance. Globally, urban bee research is

266 heavily biased towards cities in developed countries with temperate climates (Silva et al. 2021).

267 Improving the targeted nature of urban pollinator research and accomplishing this research in

268 diverse urban landscapes will bolster our capacity to integrate habitat that supplies pollination

269 services and biodiversity to cityscapes around the world. 


\section{Citations}

272 Ascher JS \& Pickering J (2013) Discover Life bee species guide and world checklist

273 (Hymenoptera: Apoidea: Anthophila). http://www.discoverlife.org/mp/20q?

274 guide=Apoidea_species. Accessed October 2018.

275 Banaszak-Cibicka W and Zmihorski M (2020) Are cities hotspots for bees? Local and regional

276 diversity patterns lead to different conclusions. Urban Ecosystems 23:713-722.

277 https://doi.org/10.1007/s11252-020-00972-w

278 Biesmeijer, J. et al. 2006. Parallel declines in pollinators and insect-pollinated plants in Britain 279 and the Netherlands. Science, 313:351-354. https://doi.org/10.1126/science.1127863

280 Buchholz S and Egerer MH (2020) Functional ecology of wild bees in cities: towards a better 281 understanding of trait-urbanization relationships. Biodiversity and Conservation 29:2779282 2801. https://doi.org/10.1007/s10531-020-02003-8

283 Cane JH, Minckley RL, Kervin LJ, Roulston TH, Williams NM (2006) Complex responses 284 within a desert bee guild (Hymenoptera: Apiformes) to urban habitat fragmentation. 285 Ecological applications. 15(2) 632-644. https://doi.org/10.1890/10510761(2006)016[0632:CRWADB]2.0.CO;2

287 Carpenter SR, Benson BJ, Biggs R, Chipman JW, Foley JA, Golding SA, Hammer RB, Hanson 
293 Cohen H, Philpott SM, Liere H, Lin BB, and Jha S (2020) The relationship between pollinator

294 community and pollination services is mediated by floral abundance in urban landscapes.

295 Urban Ecosystems 24:275-290. https://doi.org/10.1007/s11252-020-01024-z

296 Cusser S, Neff JL, Jha S (2018) Land-use history drives contemporary pollinator community

297 similarity. Landscape Ecology 33:1335-1351. https://doi.org/10.1007/s10980-018-0668-2

298 Daily GC (1997) Nature’s Services: Societal Dependence on Natural Ecosystems. Island Press, 299 Washington, DC.

300 Daniels B, Jedamski J, Ottermanns R, Ross-Nickoll M (2020) A “plan bee” for cities: Pollinator

301 diversity and plant-pollinator interactions in urban green spaces. PLoS ONE 15: e0235492.

302 https://doi.org/10.1371/journal.pone.0235492

303 Fetridge ED, Ascher JS, Langellotto GA (2008) The bee fauna of residential

304 gardens in a suburb of New York City (Hymenoptera: Apoidea). Annals of the

305 Entomological Society of America, 101:1067-1077. https://doi.org/10.1603/0013-8746-

$306 \quad 101.6 .1067$

307 Fox J, Weisberg S, Price B, Adler D, Bates D, Baud-Bovy G, Bolker B, Ellison S, Firth D,

308 Friendly M, Gorjane G, Graves S, Heiberger R, Laboissiere R (2018) ‘car’ R package.

$309 \quad$ Version 3.0-2.

310 Frankie GW, Thorp RW, Hernandez J et al. (2009) Native bees are a rich natural resource in

311 urban California gardens. California Agriculture 63:113-120.

312 https://doi.org/10.3733/ca.v063n03p113 
313 Garibaldi LA, Steffan-Dewenter I, Winfree R, Aizen MA, Bommarco R, Cunnin SA et al. 2013.

314 Wild pollinators enhance fruit set of crops regardless of honey bee abundance. Science

315 339:1608-1611. https://doi.org/10.1126/science.1230200

316 Gibbs J (2011) Revision of the metallic Lasioglossum (Dialictus) of eastern North America

317 (Hymenoptera: Halictidae: Halictini). Zootaxa 3073:1-216.

318 Goddard MA, Dougill AJ Benton TG (2010) Scaling up from gardens: biodiversity conservation

319 in urban environments. Trends in Ecology and Evolution 25:90-98.

320 https://doi.org/10.1016/j.tree.2009.07.016

321 Goulson D, Hughes W, Derwent L, Stout J (2002) Colony growth of the bumblebee, Bombus

322 terrestris, in improved and conventional agricultural and suburban habitats. Oecologia

323 130:267-273.

324 González-Varo JP, Biesmeijer JC, Bommarco R, Potts SG, Schweiger O, Smith HG, Steffan-

325 Dewenter I, Szentgyörgyi H, Woyciechowski M, Vilà M 2013. Combined effects of global

326 change pressures on animal-mediated pollination. Trends in Ecology and Evolution 28:524-

327 530. https://doi.org/10.1016/j.tree.2013.05.008

328 Goslee S and Urban D (2017) 'ecodist': R package for dissimilarity-based functions for

$329 \quad$ ecological analysis. Version 2.0.1

330 Hall DM, Camilo GR, Tonietto RK, Ollerton J, Ahrne K, Arduser M, Ascher JS, Baldock KCR,

331 Fowler R, Frankie G, Goulson D, Gunnarsson B, Hanley ME, Jackson JI, Langellotto G,

332 Lowenstein D, Minor ES, Philpott SM, Potts SG, Sirohi MH, Spevak EM, Stone GN,

333 Threlfall CG (2016) The city as a refuge for insect pollinators. Conservation Biology

334 31:24-29. https://doi.org/10.1111/cobi.12840 
Hodgson K, Caton Campbell M, Bailkey M (2011) Urban Agriculture (PAS 563): Growing

Healthy, Sustainable Places. American Planning Association. Chicago.

Larsen TH, Williams N, Kremen C (2005) Extinction order and altered community structure rapidly disrupt ecosystem functioning. Ecology Letters, 8:538-547.

Martins AC, Goncalves RB \& Melo GAR (2013) Changes in wild bee fauna of a grassland in Brazil reveal negative effects associated with growing urbanization during the last 40 years. Zoologia 30:157-176. https://doi.org/10.1590/S1984-46702013000200006

Matteson KC, Ascher JS, Langellotto GA (2008) Bee richness and abundance in New York City urban gardens. Annals of the Entomolgical Society of America 101:140-150. https://doi.org/10.1603/0013-8746(2008)101[140:BRAAIN]2.0.CO;2

McFrederick QS, LeBuhn G (2006) Are urban parks refuges for bumble bees Bombus spp. (Hymenoptera:Apidae)? Biological Conservation, 129:372-382. https://doi.org/10.1016/j.biocon.2005.11.004

McKinney ML (2008) Effects of urbanization on species richness: a review of plants and animals. Urban Ecosystems 11:161-176. http///dx.doi.org/10.1007/s11252-007-0045-4

Mitchell TB (1960) Bees of the eastern United States. I. Technical bulletin (North Carolina Agricultural Experiment Station), 141:1-538. [Introduction, Andrenidae, Colletidae, Halictidae, Mellitidae]

National Research Council (2007) Status on Pollinators in North America. The National Academies Press. Washington, D.C.

O’Connell M, Jordan Z, McGilvray E, Cohen H, Liere H, Lin BB, Philpott SM, Jha S (2021) Reap what you sow: local plant composition mediates bumblebee foraging patterns within 
urban garden landscapes. Urban Ecosystems 24:391-404. https://doi.org/10.1007/s11252-

359 Oksanen J, Guillaume Blanchet F, Friendly M, Kindt R, Legendre P, McGlinn D, Minchin PR,

360 O’Hara RB, Simpson GL, Solymos P, Henry M, Stevens H, Szoecs E, Wagner H (2018)

361 'vegan’ R package: community ecology package. Version 2.5-3.

362 Pereira FW, Carneiro L, and Goncalves RB (2021) More losses than gains in ground-nesting

363 bees over 60 years of urbanization. Urban Ecosystems 24:233-242

364 https://doi.org/10.1007/s11252-020-01030-1

365 Persson AS, Ekroos J, Olsson P, Smith HG (2020) Wild bees and hoverflies respond differently

366 to urbanization, human population density and urban form. Landscape and Urban Planning

367 204:103901. https://doi.org/10.1016/j.landurbplan.2020.103901

368

Rebele, F (1994) Urban Ecology and Special Features of Urban Ecosystems. Global Ecology and Biogeography Letters 4:173-187. https://doi.org/10.2307/2997649

370 Reeher P, Novotny JL, Mitchell RJ (2020) Urban bumble bees are unaffected by the proportion

371 of intensely developed land within urban environments of the industrial Midwestern USA.

372 Urban Ecosystems 23:703-711. https://doi.org/10.1007/s11252-020-00965-9

373 Renner SS, Graf MS, Hentschel Z, Krause H, Fleischmann A (2021) High honeybee abundances

374 reduce wild bee abundances on flowers in the city of Munich. Oecologia 195:825-831

375 https://doi.org/10.1007/s00442-021-04862-6

376 Riera JP, R Voss, SR Carpenter, TK Kratz, TM Lillesand, JA Schnaiberg, MG Turner, and MW

377 Wegener (2001) Nature, society and history in two contrasting landscapes in Wisconsin, 
USA: interactions between lakes and humans during the 20th century. Land Use Policy

379 18:41-51.

Ripley B, Venables B, Bates DM, Hornik K, Gebhardt A, Firth D (2018). MASS R package. Version 7.3-51.1.

Rosenzweig ML (2003) Reconciliation ecology and the future of species diversity. Oryx, 37:194205. https://doi.org/10.1017/S0030605303000371

384 Sakagami SF \& Michener CD (1962) The nest architecture of the sweat bees (Halictinae): a 385 comparative study of behavior. Lawrence: University of Kansas Press.

386 Sexton A, Benton S, Browning AC, Emery SM (2021) Reproductive patterns of solitary cavity387 nesting bees responsive to both local and landscape factors. Urban Ecosystems. https://doi.org/10.1007/s11252-021-01116-4

Silva, JLS, de Oliveira MTP, Cruz-Neto O, Tabarelli M, Valentina Lopes A (2021) Plantpollinator interactions in urban ecosystems worldwide: A comprehensive review including research funding and policy actions. Ambio 50:884-900. https://doi.org/10.1007/s13280020-01410-z

393 Steffan-Dewenter I, Munzenberg U, Burger C, Thies C, Tscharntke T (2002) Scale-dependent 394 effects of landscape context on three pollinator guilds. Ecology 83:1421-1432.

395 https://doi.org/10.1890/0012-9658(2002)083[1421:SDEOLC]2.0.CO;2

396 Theodorou P, Radzevidiute R, Settele J, Schweiger O, Murray TE, Paxton RJ (2016) Pollination services enhanced with urbanization despite increasing pollinator parasitism. Proceedings 
399 Theodorou P, Herbst SD, Kahnt B, Landaverde-Gonzalez P, Baltz LM, Osterman J, and Paxton

400 R (2020) Urban fragmentation leads to lower floral diversity, with knock-on impacts on

401 bee biodiversity. Scientific Reports 10:21756 https://doi.org/10.1038/s41598-020-78736-X

402 Threlfall CG, Walker K, Williams NSG, Hahs AK, Mata L, Stork N \& Livesley SJ (2015) The

403 conservation value of urban green space habitats for Australian native bee communities.

404 Biological Conservation 187:240-248.

405 Tonietto R, Fant J, Ascher J, Ellis K \& Larkin D (2011) A comparison of bee communities of

406 Chicago green roofs, parks, and prairies. Landscape and Urban Planning 103:102-108.

407 Turo KJ, Spring MR, Sivakoff FS, Delgado de la flor YA, Gardiner MM (2019) Conservation in

408 post-industrial cities: How does vacant lot management and landscape configuration

409 influence urban bees. Journal of Applied Ecology 58:58-69. https://doi.org/10.1111/1365-

$410 \quad 2664.13773$

411 USDA National Agricultural Statistics Service Cropland Data Layer. 2013. Published crop-

412 specific data layer [Online]. Available at http://nassgeodata.gmu.edu/CropScape/

413 (accessed 2014; verified 2014). USDA-NASS, Washington, DC.

414 Wegener MW (2001) Long-term land use/cover change patterns in the Yahara Lakes region and

415 their impact on runoff volume to Lake Mendota. Master’s thesis. University of Wisconsin,

416 Madison

417 Winfree R, Aguilar R Vazquez DP, LeBuhn G, Aizen MA (2009) A meta-analysis of bees'

418 responses to anthropogenic disturbance. Ecology 90:2068-2076. https://doi.org/10.1890/08-

$419 \quad 1245.1$ 
bioRxiv preprint doi: https://doi.org/10.1101/2021.11.19.469286; this version posted November 19, 2021. The copyright holder for this preprint (which was not certified by peer review) is the author/funder, who has granted bioRxiv a license to display the preprint in perpetuity. It is made available under aCC-BY 4.0 International license.

420 Wojcik VA, Frankie GW, Thorp RW, Hernandz JL (2008) Seasonality in bees and their floral

421 resource plants at a constructed urban bee habitat in Berkeley, California. Journal of the

$422 \quad$ Kansas Entomological Society 81:15-28. https://doi.org/10.2317/JKES-701.17.1

423 
bioRxiv preprint doi: https://doi.org/10.1101/2021.11.19.469286; this version posted November 19,2021 . The copyright holder for this preprint (which was not certified by peer review) is the author/funder, who has granted bioRxiv a license to display the preprint in perpetuity. It is made available under aCC-BY 4.0 International license.

424 Figure 1. Map of urban bee community sampling sites selected in a spatially stratified design

425 across the City of Madison, (a) surrounded by 200m buffers, filled with impervious land cover

426 and (b) overlaid on kriged property development year surface.
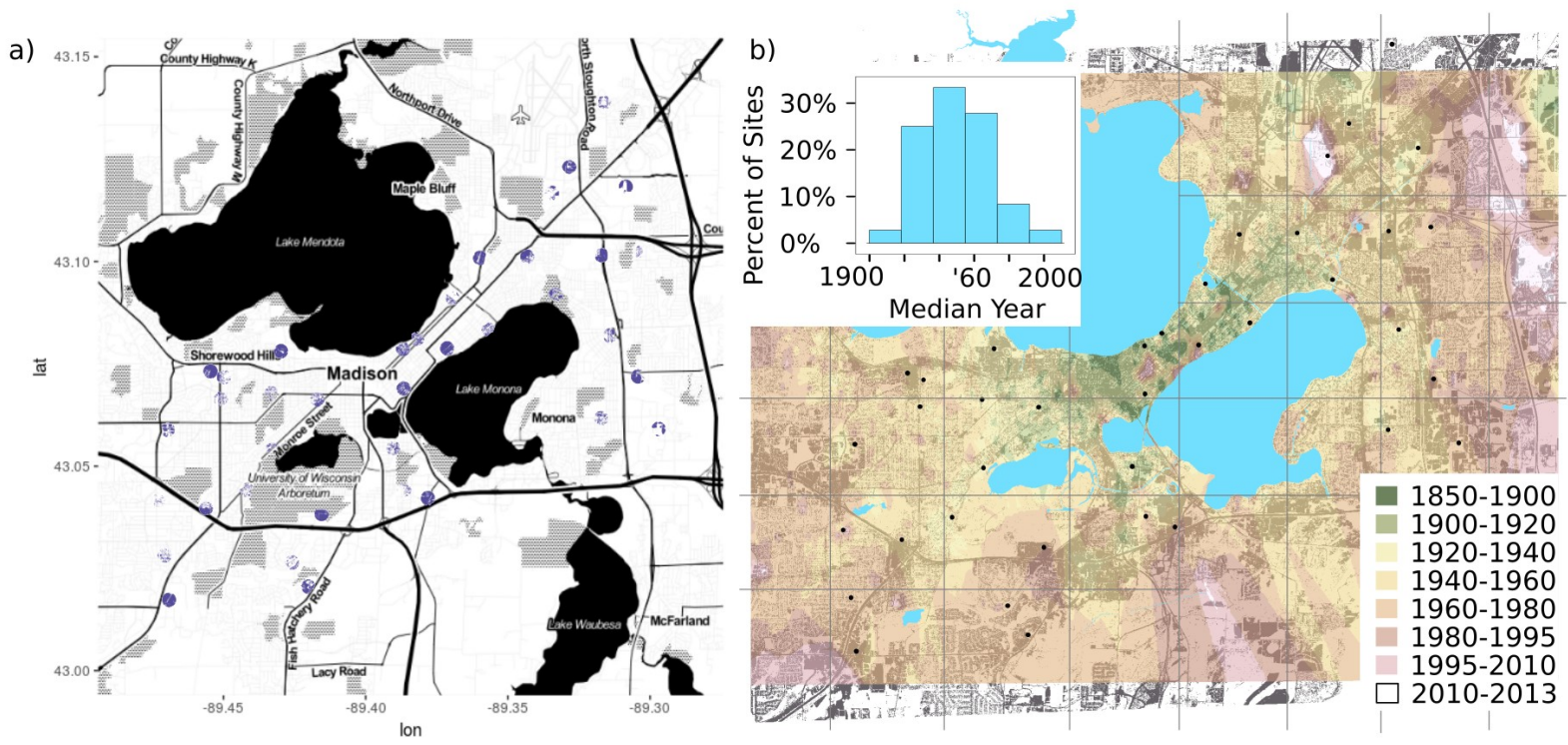
bioRxiv preprint doi: https://doi.org/10.1101/2021.11.19.469286; this version posted November 19, 2021. The copyright holder for this preprint (which was not certified by peer review) is the author/funder, who has granted bioRxiv a license to display the preprint in perpetuity. It is made available under aCC-BY 4.0 International license.

429 Figure 2. Species accumulation curves for overall site species richness with site numbers.

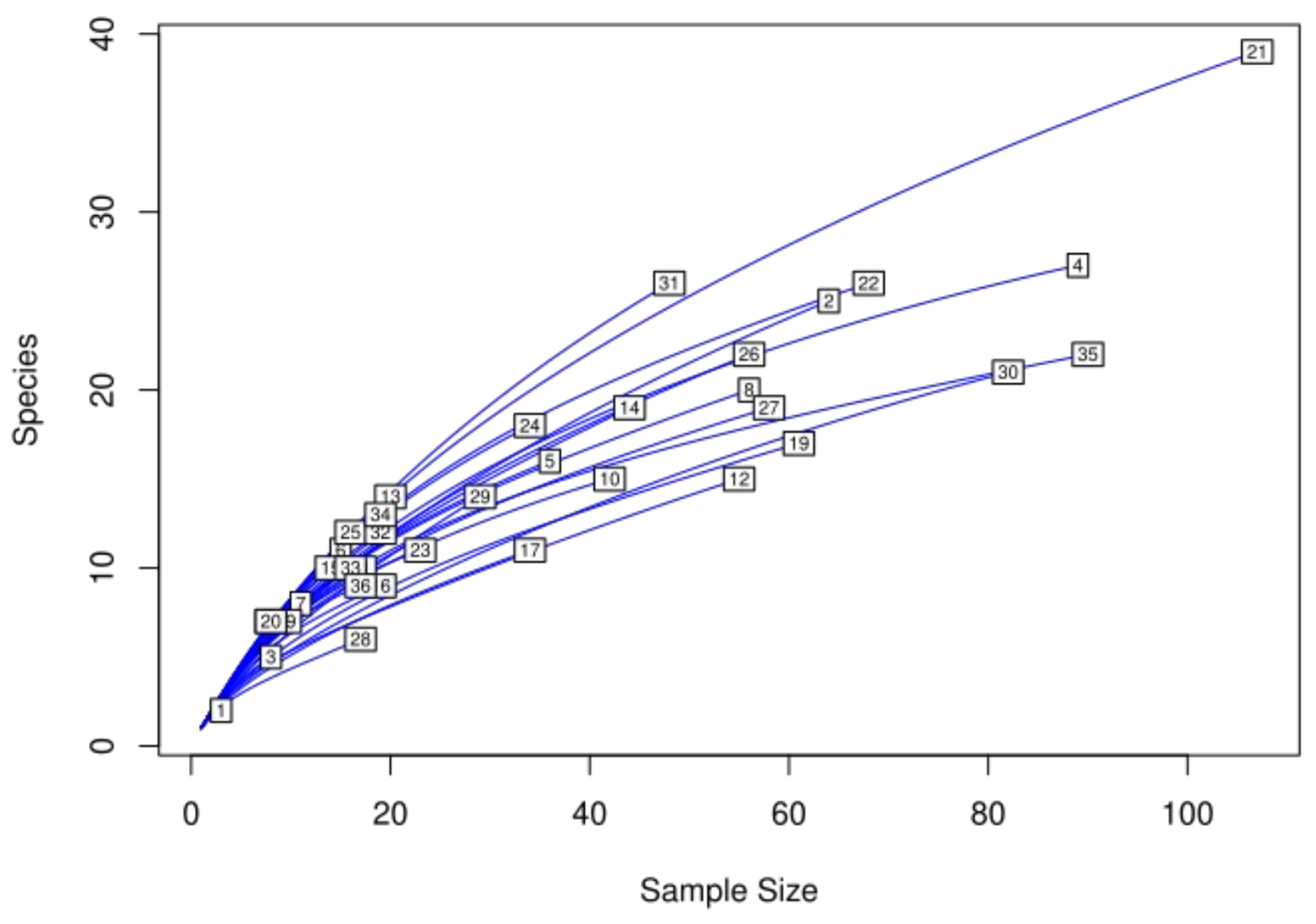


431 Figure 3. Average bee abundance and species richness for older neighborhoods and recently

432 developed neighborhoods with median property development year in the surrounding 200m

433 landscape sector before or after 1960.

434
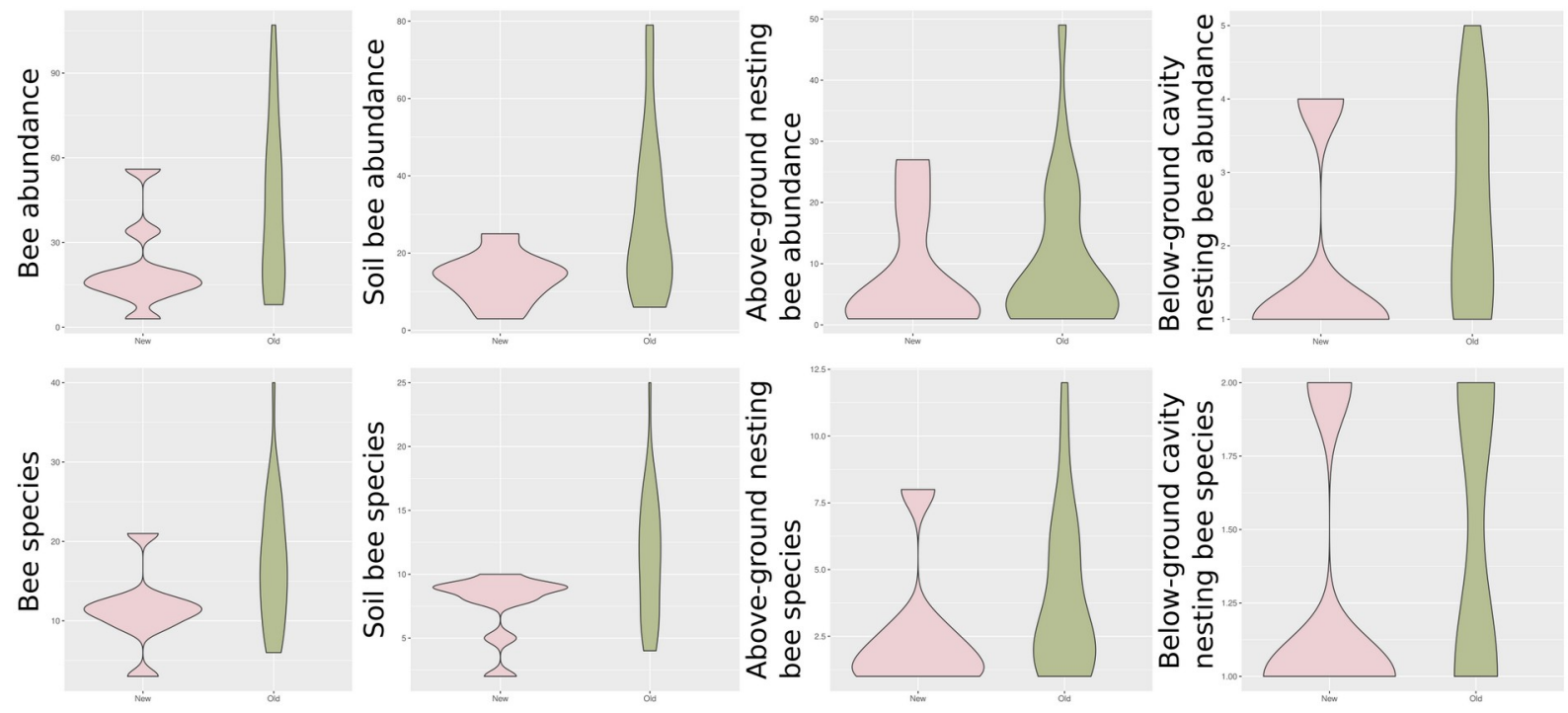

436

437

438 
bioRxiv preprint doi: https://doi.org/10.1101/2021.11.19.469286; this version posted November 19, 2021. The copyright holder for this preprint (which was not certified by peer review) is the author/funder, who has granted bioRxiv a license to display the preprint in perpetuity. It is made available under aCC-BY 4.0 International license.

439 Table 1. Results of top AICc-selected multiple linear regression models for species richness of a.

440 the full bee community, b. soil-nesting bees, c. cavity-nesting bees, and d. above-ground bees.

441 Table 1. Best AICc-selected multivariate linear regression models

Full bee community

442

\begin{tabular}{|c|c|c|c|c|c|}
\hline Variable & Estimate & Std Error & $P$ & Model $a d j R^{2}$ & $P$ \\
\hline Intercept & 16.355 & 1.312 & $>0.001$ & 0.217 & 0.007 \\
\hline Develop & -5.554 & 2.631 & 0.042 & & \\
\hline Imp200 & -2.880 & 1.140 & 0.017 & & \\
\hline \multicolumn{6}{|c|}{ Soil nesting bee community } \\
\hline Variable & Estimate & Std Error & $P$ & Model $a d j R^{2}$ & $P$ \\
\hline Intercept & 0.460 & 0.817 & $>0.001$ & 0.197 & 0.010 \\
\hline Develop & -3.387 & 1.638 & 0.047 & & \\
\hline Imp200 & -1.667 & 0.710 & 0.025 & & \\
\hline \multicolumn{6}{|c|}{ Above ground nesting bee community } \\
\hline Variable & Estimate & Std Error & $P$ & Model adj $R^{2}$ & $P$ \\
\hline Intercept & 3.630 & 0.492 & $>0.001$ & 0.0954 & 0.0475 \\
\hline Imp200 & -1.029 & 0.500 & 0.048 & & \\
\hline \multicolumn{6}{|c|}{ Below ground cavity nesting bee community } \\
\hline Variable & Estimate & Std Error & $P$ & Model adj $R^{2}$ & $P$ \\
\hline Intercept & 0.460 & 0.294 & 0.131 & 0.426 & 0.002 \\
\hline For1000 & -0.357 & 0.494 & 0.477 & & \\
\hline For200 & -1.022 & 0.392 & 0.015 & & \\
\hline
\end{tabular}


bioRxiv preprint doi: https://doi.org/10.1101/2021.11.19.469286; this version posted November 19, 2021. The copyright holder for this preprint (which was not certified by peer review) is the author/funder, who has granted bioRxiv a license to display the preprint in perpetuity. It is made available under aCC-BY 4.0 International license.

\section{Table 2. Model average coefficients for the 95\% confidence model set of AICc-selected multiple}

444 linear regression models for species richness of a. the full bee community, b. soil-nesting bees, c.

445 cavity-nesting bees, and d. above-ground bees.

Table 2. 95\% confidence model set average coefficients for species richness multiple variate linear regressions

Full bee community

\begin{tabular}{|c|c|c|c|c|c|c|c|c|}
\hline Variable & Intercept & Forest $(1 \mathrm{~km})$ & Nat Veg $(1 \mathrm{~km})$ & $\operatorname{Imp}(1 \mathrm{~km})$ & Forest $(200 \mathrm{~m})$ & Nat Veg $(200 \mathrm{~m})$ & $\operatorname{Imp}(200 \mathrm{~m})$ & Development \\
\hline Model Avg Coef & 15.997 & 0.250 & -0.061 & 0.029 & -0.27 & -0.798 & -3.049 & -5.725 \\
\hline Sum of Weights & & 0.250 & 0.190 & 0.180 & 0.25 & 0.22 & 0.89 & 0.72 \\
\hline \multicolumn{9}{|c|}{ Soil nesting bee community } \\
\hline Variable & Intercept & Forest $(1 \mathrm{~km})$ & Nat Veg $(1 \mathrm{~km})$ & Imp (1km) & Forest $(200 \mathrm{~m})$ & Nat Veg $(200 \mathrm{~m})$ & Imp (200m) & Development \\
\hline Model Avg Coef & 11.134 & 0.807 & 0.329 & -0.131 & -0.327 & -0.457 & -1.724 & -3.608 \\
\hline Sum of Weights & & 0.290 & 0.200 & 0.180 & 0.21 & 0.22 & 0.82 & 0.73 \\
\hline \multicolumn{9}{|c|}{ Above ground bee community } \\
\hline Variable & Intercept & Forest $(1 \mathrm{~km})$ & Nat Veg $(1 \mathrm{~km})$ & Imp $(1 \mathrm{~km})$ & Forest $(200 \mathrm{~m})$ & Nat Veg $(200 \mathrm{~m})$ & $\operatorname{Imp}(200 \mathrm{~m})$ & Development \\
\hline Model Avg Coef & 3.695 & -0.169 & -0.641 & -0.054 & -0.009 & -0.337 & -0.679 & -0.316 \\
\hline Sum of Weights & & 0.180 & 0.360 & 0.180 & 0.18 & 0.22 & 0.67 & 0.27 \\
\hline \multicolumn{9}{|c|}{ Below ground cavity bee community } \\
\hline Variable & Intercept & Forest $(1 \mathrm{~km})$ & Nat Veg $(1 \mathrm{~km})$ & Imp $(1 \mathrm{~km})$ & Forest $(200 \mathrm{~m})$ & Nat Veg $(200 \mathrm{~m})$ & $\operatorname{Imp}(200 \mathrm{~m})$ & Development \\
\hline Model Avg Coef & 1.434 & -0.129 & 0.092 & -0.027 & 0.368 & 0.081 & -0.092 & -0.017 \\
\hline Sum of Weights & & 0.520 & 0.170 & 0.200 & 0.51 & 0.15 & 0.14 & 0.12 \\
\hline
\end{tabular}


bioRxiv preprint doi: https://doi.org/10.1101/2021.11.19.469286; this version posted November 19, 2021. The copyright holder for this preprint (which was not certified by peer review) is the author/funder, who has granted bioRxiv a license to display the preprint in perpetuity. It is made available under aCC-BY 4.0 International license.

448 Table 3. Multiple regression on distance matrices to assess the influence of geographic distance,

449 neighborhood development, and land cover on the full bee community, soil-nesting bees, above-

450 ground nesting bees, and d. below-ground cavity nesting bees.

451 Table 3. Multiple regression on distance matrices to investigate bee community beta-diversity

\begin{tabular}{|c|c|c|c|c|c|}
\hline \multicolumn{6}{|l|}{ Full bee community } \\
\hline Variable & Regression Coefficients & $P$ & $F$-value & Model $R^{2}$ & $P$ \\
\hline Intercept & $5.55 \times 10^{-1}$ & 0.81 & 2.78 & 0.02 & 0.007 \\
\hline Geographic distance & $1.03 \times 10^{-6}$ & 0.28 & & & \\
\hline Neighborhood development & $8.61 \times 10^{-4}$ & 0.18 & & & \\
\hline Land cover $(200 \mathrm{~m})$ & $-1.83 \times 10^{-4}$ & $0.04 *$ & & & \\
\hline Land cover $(1000 \mathrm{~m})$ & $1.53 \times 10^{-4}$ & 0.43 & & & \\
\hline \multicolumn{6}{|c|}{ Full bee community - Final model } \\
\hline Variable & Regression Coefficients & $P$ & $F$-value & Model $R^{2}$ & $P$ \\
\hline Intercept & 0.570 & 0.030 & 9.690 & 0.02 & 0.09 \\
\hline Land cover $(200 \mathrm{~m})$ & $-1.86 \times 10^{-4}$ & $0.03 *$ & & & \\
\hline \multicolumn{6}{|l|}{ Soil nesting bee community } \\
\hline Variable & Regression Coefficients & $P$ & $F$-value & Model $R^{2}$ & $P$ \\
\hline Intercept & $4.92 \times 10^{-1}$ & 1.000 & 4.160 & 0.030 & 0.020 \\
\hline Geographic distance & $2.16 \times 10^{-6}$ & $0.04 *$ & & & \\
\hline Neighborhood development & $7.51 \times 10^{-4}$ & 0.260 & & & \\
\hline Land cover $(200 \mathrm{~m})$ & $-1.70 \times 10^{-4}$ & $0.04 *$ & & & \\
\hline Land cover $(1000 \mathrm{~m})$ & $-1.26 \times 10^{-4}$ & 0.500 & & & \\
\hline \multicolumn{6}{|c|}{ Soil nesting bee community - Final model } \\
\hline Variable & Regression Coefficients & $P$ & $F$-value & Model $R^{2}$ & $P$ \\
\hline Intercept & $4.91 \times 10^{-1}$ & 0.97 & 7.390 & 0.020 & 0.010 \\
\hline Geographic distance & $-1.70 \times 10^{-4}$ & $0.04 *$ & & & \\
\hline Land cover $(200 \mathrm{~m})$ & $2.18 \times 10^{-6}$ & $0.04 *$ & & & \\
\hline \multicolumn{6}{|c|}{ Above ground nesting bee community } \\
\hline Variable & Regression Coefficients & $P$ & $F$-value & Model $R^{2}$ & $P$ \\
\hline Intercept & $8.13 \times 10^{-1}$ & 0.110 & 1.590 & 0.01 & 0.36 \\
\hline Geographic distance & $-1.84 \times 10^{-6}$ & 0.210 & & & \\
\hline Neighborhood development & $1.65 \times 10^{-4}$ & 0.480 & & & \\
\hline Land cover $(200 \mathrm{~m})$ & $3.33 \times 10^{-4}$ & 0.680 & & & \\
\hline Land cover $(1000 \mathrm{~m})$ & $-3.71 \times 10^{-4}$ & 0.170 & & & \\
\hline \multicolumn{6}{|c|}{ Above ground nesting bee community - Final model } \\
\hline Variable & Regression Coefficients & $P$ & $F$-value & Model $R^{2}$ & $P$ \\
\hline Intercept & $7.69 \times 10^{-1}$ & 0.270 & 2.130 & 0 & 0.14 \\
\hline Land cover $(1000 \mathrm{~m})$ & $-4.00 \times 10^{-4}$ & 0.140 & & & \\
\hline \multicolumn{6}{|c|}{ Below ground cavity nesting bee community } \\
\hline Variable & Regression Coefficients & $P$ & $F$-value & Model $R^{2}$ & $P$ \\
\hline Intercept & $3.76 \times 10^{-1}$ & 0.95 & 5.810 & 0.070 & 0.040 \\
\hline Geographic distance & 5.07 & 0.08 . & & & \\
\hline Neighborhood development & -2.55 & 0.63 & & & \\
\hline Land cover $(200 \mathrm{~m})$ & $-4.30 \times 10^{-4}$ & 0.92 & & & \\
\hline Land cover $(1000 \mathrm{~m})$ & $-3.60 \times 10^{-3}$ & 0.6 & & & \\
\hline \multicolumn{6}{|c|}{ Below ground cavity nesting bee community - Final model } \\
\hline Variable & Regression Coefficients & $P$ & $F$-value & Model $R^{2}$ & $P$ \\
\hline Intercept & $3.72 \times 10^{-1}$ & 0.96 & 3.810 & 0.030 & 0.070 \\
\hline Land cover (1000m) & $5.23 \times 10^{-6}$ & 0.07 . & & & \\
\hline
\end{tabular}


452 Supplemental Table 1

453

454 Bee species

455 Agapostemon sericeus

456 Agapostemon virescens

457 Andrena bisalicis

458 Andrena crataegi

459 Andrena erythronii

460 Andrena milwaukensis

461 Andrena nasonii

462 Andrena nigrae

463 Andrena nuda

464 Andrena phaceliae

465 Andrena wellesleyana

466 Anthidium maculifrons

467 Anthidium manicatum

468 Anthidium oblongatum

469 Apis mellifera

470 Augochlora pura

471 Augochlorella aurata

472 Augochlorella persimilis

473 Augochlorella sp

474 Augochloropsis fulgada

475 Bombus affinis

476 Bombus bimaculatus

477 Bombus fervidus

478 Bombus griseocollis

479 Bombus impatience

480 Bombus rufosphinctus

481 Bombus sandersoni

482 Ceratina calcarata

483 Ceratina dupla

484 Ceratina mikmaqi

485 Ceratina strenua

486 Coelioxys spp

487 Colletes spp

488 Eucera atriventris

489 Florilegus condiginus

490 Halictus confusus

491 Halictus ligatus

492 Halictus parallelus

493 Halictus rubicundus

494 Hylaeus affinus

495 Hylaeus annulatus 


\begin{tabular}{|c|c|}
\hline 496 & Hylaeus floridanus \\
\hline 497 & Hylaeus mesillae \\
\hline 498 & Hylaeus rudbeckiae \\
\hline 499 & Lasioglossum albepenne \\
\hline 500 & Lasioglossum anomalum \\
\hline 501 & Lasioglossum atwoodi \\
\hline 502 & Lasioglossum atwoodii \\
\hline 503 & Lasioglossum bruneri \\
\hline 504 & Lasioglossum cattelae \\
\hline 505 & Lasioglossum coreopsis \\
\hline 506 & Lasioglossum corerulevum \\
\hline 507 & Lasioglossum coriaceum \\
\hline 508 & Lasioglossum cressoni \\
\hline 509 & Lasioglossum divergens \\
\hline 510 & Lasioglossum egregium \\
\hline 511 & Lasioglossum hartii \\
\hline 512 & Lasioglossum illinosese \\
\hline 513 & Lasioglossum imatatum \\
\hline 514 & Lasioglossum leucozonium \\
\hline 515 & Lasioglossum lineatulum \\
\hline 516 & Lasioglossum michiganense \\
\hline 517 & Lasioglossum nigrovirde \\
\hline 518 & Lasioglossum nymphacorum \\
\hline 519 & Lasioglossum obscurum \\
\hline 520 & Lasioglossum paraforbesii \\
\hline 521 & Lasioglossum pilosum \\
\hline 522 & Lasioglossum pruinosum \\
\hline 523 & Lasioglossum spp \\
\hline 524 & Lasioglossum tegulare \\
\hline 525 & Lasioglossum timothyi \\
\hline 526 & Lasioglossum versans \\
\hline 527 & Lasioglossum weems \\
\hline 528 & Lasioglossum weemsi \\
\hline 529 & Lasioglossum zephyrum \\
\hline 530 & Lasioglossum zonulum \\
\hline 531 & Megachile inimica \\
\hline 532 & Megachile latimanus \\
\hline 533 & Megachile melanophoea \\
\hline 534 & Megachile mendica \\
\hline 535 & Megachile relativa \\
\hline 536 & Melissodes agilis \\
\hline 537 & Melissodes bimaculatus \\
\hline 538 & Melissodes boltonae \\
\hline 539 & Melissodes comunis \\
\hline
\end{tabular}


bioRxiv preprint doi: https://doi.org/10.1101/2021.11.19.469286; this version posted November 19, 2021. The copyright holder for this preprint (which was not certified by peer review) is the author/funder, who has granted bioRxiv a license to display the preprint in perpetuity. It is made available under aCC-BY 4.0 International license.

540 Melissodes dentiventris

541 Melissodes druriellus

542 Melissodes rustica

543 Melissodes tinctus

544 Melissodes trinodis

545 Nomada affabilis

$546 \quad$ Nomada articulata

547 Nomada cressoni

548 Nomada illinoensis pygmaea

549 Osmia sp.

550 Sphecodes sp.

551 Stelis louisae

552 Stelis nitida

553 